To Maega | Jurnal Pengabdian Masyarakat

Oktober 2021, Vol. 4, No.3, hal. 395-405

$\operatorname{ISSN}(P): 2622-6332 ; \operatorname{ISSN}(E): 2622-6340$

http://www.ojs.unanda.ac.id/index.php/tomaega

\title{
Pelatihan Manajemen Bisnis Ikan Hias Karang : Upaya Meningkatkan Pendapatan Nelayan di Pulau Barrang Lompo
}

\author{
Akmal Abdullah ${ }^{1 *}$, Mauli Kasmi ${ }^{1}, \operatorname{Karma}^{1}$, Ilyas ${ }^{1}$ \\ ${ }^{1}$ Program Studi Agribisnis Perikanan, Politeknik Pertanian Negeri Pangkep \\ *Correspondent Email: akmalabdullah23@gmail.com
}

\section{Article History:}

Received: 29-09-2021; Received in Revised: 22-10-2021; Accepted: 29-10-2021

DOI: http://dx.doi.org/10.35914/tomaega.v4i3.903

\begin{abstract}
Abstrak
Kegiatan pelatihan ini bertujuan untuk memberikan pemahaman dan keterampilan kepada mitra UKM dan kelompok nelayan agar terjadi peningkatan dalam pendapatan mitra. Kegiatan ini dilaksanakan di Pulau Barrang Lompo Kota Makassar. Adapun metode dan tahapan pengabdian yang digunakan adalah Tahap desk study, tahap memberikan sosialilasi atau pelatihan terkait manajemen bisnis ikan karang hias dan tahap penerapan teknologi ikan hias dan karang hias dan pendampingan kepada mitra selama pemiliharaan karang hias serta tahap Evaluasi. Hasil dari kegiatan pengabdian ini bisa dilihat dari meningkatnya pengetahuan dan keterampilan mitra dalam penerapan manajemen bisnis yang baik jika serta tata kelola usaha. meningkatnya pengetahuan tentang teknik pemasaran ikan hias karang yang lebih modern, tertibnya pengadministrasi keuangan usaha mitra, sehingga pembukuan usaha mitra sudah tercatat dengan baik dan benar dan pengetahuan tentang regulasi pemerintah tentang perdagangan bisnis ikan hias karang. Kata Kunci : Manajemen Bisnis, Ikan Hias Karang, UKM.
\end{abstract}

\begin{abstract}
This training activity aims to provide understanding and skills to SME partners and fishing groups so that there is an increase in partner income. This activity was carried out on Barrang Lompo Island, Makassar City. The methods and stages of service used are the desk study stage, the stage of providing socialization or training related to ornamental reef fish business management and the stage of applying ornamental fish and ornamental coral technology and assistance to partners during the selection of ornamental corals and the Evaluation stage. The results of this service activity can be seen from the increased knowledge and skills of partners in implementing good business management as well as business governance. increased knowledge of more modern coral ornamental fish marketing techniques, orderly financial administration of partner businesses, so that the partner's business books have been recorded properly and correctly and knowledge of government regulations regarding trade of coral ornamental fish business.
\end{abstract}

Key Words : Business Management, Coral Ornamental Fish, SmeS.

\section{Pendahuluan}

Ikan hias karang sangat diminati oleh kalangan masyarakat disebabkan karena ikan hias karang memiliki eksotisme tersendiri, diantaranya dari dengan keindahan dari warna, corak dan bentuk yang berbeda dari setiap jenis, sehingga banyak diperdagangkan sebagai produk yang mempunyai nilai hiburan karena 
dapat memiliki pasar tertentu pada kalangan masyarakat. Terumbu karang merupakan ekosistem pesisir yang memiliki produktivitas tinggi. Hal ini menyebabkan terumbu karang menjadi habitat bagi beraneka macam biota laut. Biota-biota yang memanfaatkan terumbu karang sebagai habitatnya antara lain ikan-ikan karang, bulu babi, kima, bintang laut, teripang, dan lain-lain. Sebagian besar biota tersebut merupakan sumberdaya yang dapat dimanfaatkan oleh manusia untuk berbagai macam keperluan. Salah satunya adalah sumberdaya ikan karang. Warna serta bentuknya yang menarik menjadikan ikan karang sering dimanfaatkan sebagai ikan hias (Anggoro et al., 2013).

Kementerian Kelautan dan Perikanan, n.d. (2021) dalam rilisnya mengatakan Indonesia berpeluang merebut pangsa pasar ikan hias dunia. Data trademap menunjukkan, sejak tahun 2016-2019, Indonesia berada di peringkat keempat sebagai eksportir ikan hias dunia setelah Jepang, Singapura dan Spanyol. Adapun 5 negara utama tujuan ekspor ikan hias Indonesia adalah Tiongkok, Amerika Serikat, Rusia, Kanada, dan Singapura. Berdasarkan angka sementara Badan Pusat Statistik (BPS) yang diolah Direktorat Jenderal Penguatan Daya Saing Produk Kelautan dan Perikanan (PDSPKP), nilai ekspor ikan hias Indonesia pada periode Januari-Maret 2021 mencapai USD9,2 juta. Capaian ini menjadi yang paling besar dibanding 4 tahun terakhir pada periode yang sama (Kementerian Kelautan dan Perikanan, n.d.)

Salah satu sentra produksi ikan hias karang yang ada di Indonesia adalah Pulau Barrang Lompo Kota Makassar Sulawesi Selatan. Produksi Ikan hias karang di pulau Barrang lompo merupakan sentra produksi ikan hias karang untuk ekspor khususnya wilayah Sulawesi Selatan. Dengan banyaknya jumlah produksi ikan hias yang terdapat di Pulau Barrang Lompo ini dapat menciptakan suatu peluang usaha di bidang perdagangan ikan hias, karena jumlah ketersediaan ikan hias sebagai produk dengan kualitas, kuantitas dan kontinuitasnya terjamin.(Akmal Abdullah et al., 2020) Selain itu potensi yang lain cukup ialah melihat minat masyarakat yang cukup tinggi terhadap ikan hias karang ini. Hal tersebut dapat dilihat dari banyaknya tempat penjualan ikan hias yang dapat dijumpai di marketplace maupun di pasar hobby. Mulai dari yang skala lebih kecil hingga skala yang lebih besar nampak selalu ramai pada akhir pekan dan hari-hari libur.

Dengan banyakanya pengusaha ikan hias karang ini, maka akan menimbulkan semakin bertambah dan ketatnya persaingan untuk memperebutkan pasar yang sama. Maka dari itu para pelaku usaha di sektor ikan hias karang perlu mengetahui apa sebenarnya yang menjadi keinginan dan kebutuhan konsumen. Jika pengusaha ikan hias cukup banyak, maka akan menyebabkan semakin tingginya tingkat persaingan untuk memperebutkan konsumen pencinta ikan hias. Tiap toko ikan hias mempunyai keungulan yang berbeda satu dengan yang lain dalam memasarkan produknya, makapengusahan di kalangan ikan hias perlu mengetahui apa yang menjadi keinginan konsumen dan berusaha agar konsumennya merasa puas, sehingga akan melakukan pembelian kembali (Pagalung et al., 2020) 
Pemanfaat ikan hias karang masih tergantung pada keberadaan populasi di sepanjang terumbu karang. Untuk ornament akurium air laut dengan pemandangan eksotis dengan pajangan karang hias. Alternative untuk mengatasi bebagai masalah lingkungan seperti akibat penangkapan ikan tidak ramah lingkungan dan upaya mengatasi eksploitasi berlebihan oleh nelayan untuk diperdagangkan baik local ataupun ekspor sebagai ornament akarium dengan harga relative mahal. Seiring dengan peningkatannya permintaan karang hias alam sehingga perlu membudayakan masyarakat nelayan melakukan budidaya karang hias untuk mengurangi ketergan- tungan dari alam. ekspor sebagai ornament akarium dengan harga relative mahal (Mauli Kasmi, Asriany, Andi Ridwan Makkulawu, Arif Fuddin Usman, n.d.(2021).

Pulau Barrang Lompo merupakan salah satu bagian daerah spermonde yang memiliki perairan memiliki potensi terumbu karang yang cukup luas dengan variasi jenis ikan karang yang tergolong cukup banyak yang dapat dimanfaatkan sebagai ikan konsumsi dan ikan hias. Keragaman hayati yang besar, ekosistem beragam dan wilayah yang demikian luas dengan jumlah pulau-pulau yang banyak menimbulkan kesulitan dalam pengelolaannya yang optimal, termasuk dalam pemanfaatan biota laut hias (Abdullah et al., 2021).

Bagi pelaku Usaha Kecil Menengah (UKM), dalam memasarkan produknya dibutuhkan usaha yang maksimal. Terlebih bagi usaha yang baru dirintis, seperti halnya usaha kecil yang digerakkan oleh masyarakat memiliki banyak kendala untuk dikembangkan, salah satunya adalah masalah pemasaran dan regulasi dari pemerintah. Ikan hias laut sangat diminati oleh negara-negara maju dan berkembang, kebanyakan konsumen yang hobi ikan hias laut sebagai hewan peliharaan untuk dijadikan ornament akuarium atau dekorasi prabot rumah atau tempat kerjanya. Perdagangan ikan hias Indonesia dalam periode 2000-2013 terus mengalami peningkatan (Abdullah et al., 2021). Keberadaan UMKM tidak dapat dihapuskan ataupun dihindarkan dari masyarakat bangsa saat ini. Karena keberadaannya sangat bermanfaat dalam hal pendistribusian pendapatan masyarakat (Suci et al., 2017).

Permasalahan utama kelompok nelayan dan mitra UKM ini adalah (1) Belum diterapkannya manajemen bisnis yang baik, jika dilihat dari tata kelola usaha yang masih bersifat konvensional (2). Teknik pemasaran masih tergolong sederhana dengan menunggu pengepul datang ke lokasi untuk mengambil ikan hias karang, (3). Pengadministrasi keuangan masih sederhana, sehingga diperlukan pembukuan usaha yang baik dan benar.(4) Kurangnya pengetahuan tentang regulasi dalam bisnis ikan hias karang. Bahwa Standar, regulasi teknis, dan penilaian kesesuaian juga berperan penting dalam peningkatan daya saing serta nilai tambah pada pelaksanaan strategi tersebut. Industri Mikro kecil dan menengah

Industri Mikro kecil dan menengah merupakan bagian integral dunia usaha nasional dan mempunyai kedudukan, potensi, dan peranan yang sangat penting dan strategis dalam meningkatkan perekonomian secara nasional. Selama in Usaha 
mikro kecil selain berperan dalam meningkatkan ekonomi nasional juga dapat mengurangi pengangguran. UMKM juga terlibat dalam pemerataan hasil pembangunan. Ini membuktikan bahwa UMKM kembali terbukti tidak terpengaruh oleh krisis keuangan global (Profil bisnis UKM, 2015). Namun sejak awal tahun 2020 UMKM di Indonesia telah dihadapkan pada virus corona atau COVID-19 yang telah menyerang seluruh dunia, termasuk Indonesia. Virus telah menginfeksi kesehatan masyarakat sehingga membuat kondisi kesehatan masyarakat memburuk (Riyadi \& Mujanah, 2021)

Berdasarkan beberapa permasalahan mitra tersebut maka solusi yang tawarkan adalah sebagai berikut : (1) Memberikan pengetahuan bagaimana mengelola usaha dengan baik. (2) Memberikan pengetahuan mengenai teknik memasarkan ikan hias karang (3) Mengadakan pelatihan dan pendampingan pembukuan untuk usaha, dan (3) dan (4) Sosialisasi tentang regulasi yang berlaku dalam bisnis ikan hias karang.

\section{Metode}

Beberapa bentuk pemberdayaan yang dapat dilakukan untuk membantu menumbuhkan serta meningkatkan intensi berwirausaha pada masyarakat melalui adanya penyuluhan, pelatihan dan bahkan praktek langsung (Mulasari et al., 2021) Melalui kegiatan pelatihan manajemen bisnis ikan karang hias dan regulasi Bisnis ikan hias karang menjadi produk unggulan daerah dilakukan pada Kegiatan program ini untuk pelatihan dilaksanakan pada tanggal 17 - 18 Agustus 2021 di Pulau Barrang Lompo Kecamatan Kepulauan Sangkarrang Makassar. Pelaksanaan kegiatannya berupa pelatihan manajemen dan regulasi bisnis dikuti oleh mitra UKM Mitra Bahari dan Kelompok Nelayan. Adapun metode dan tahapan yang digunakan dalam menyelesaikan permasalahan mitra tersebut diatas adalah sebagai berikut:

1. Tahap desk study, pada tahap ini dilakukan diskusi secara intensif dengan mitra untuk mengetahui urgensi kebutuhan mitra serta mengambil kesimpulan terkait prioritas permasalahan yang akan diselesaikan. Pada tahap ini juga turut dilakukansegala bentuk perencanaan serta perancangan terkait kegiatan yang akandilaksanakan dengan turut melibatkan mitra.

2. Memberikan pelatihan dan sosialisasi dan pelatihan terkait manajemen bisnis ikan karang hias dan regulasi Bisnis ikan hias karang

3. Tahap penerapan teknologi dan pendampingan kepada mitra dalam hal Manajemenbisnis dan teknik dalam pemasaran serta pembukuan .

4. Tahap Evaluasi: Evaluasi yang dilaksanakan oleh tim secara berkala yaitu pada bulan pertama setelah pelatihan manajemen bisnis usaha ikan hias karang serta serta Pendampingan pembukuan usaha kepada kedua mitra.

Evaluasi awal yang dilakukan bertujuan untuk melihat kendala yang dihadapi setelah program implementasikan. Sedangkan evaluasi pada akhir program dilakukan untuk melihat tingkat keberhasilan dan keberlanjutan program setelah masa kegiatan berakhir. Indikator evaluasi tersebut berupa: 
a. Melihat tingkat berapa kebutuhan (urgensi) Pelatihan yang akan diterapkan

b. Peran mitra dalam kegiatan. Kemampuan mitra dalam penerapan manajemen bisnis ikan hias karang.

c. Kemampuan mitra dalam melakukan pembukuan dan mengatasi kendala selama melakukan usaha ikan hias karang.

d. Peningkatan produktivitas mitra.

\section{Hasil dan Pembahasan}

Kegiatan Pengabdian ini diadakan oleh Tim PPPUD Politeknik Pertanian Negeri Pangkep berupa Pelatihan, Pendampingan dan Sosialisasi Manajemen Bisnis dan yang diselenggarakan di Pulau Barrang Lompo, Pada Hari Sabtu 17 -18 Agustus 2021. Pengabdian Kepada Masyarakat ini berisi beragam materi yang disampaikan kepada kelompok nelayan mitra dan UKM Bahari Timur.

\section{a. Pelatihan Manajemen Bisnis}

Kegiatan ini dimulai dengan pelatihan berjudul "Manajemen Bisnis Ikan Hias Karang" dimana mitra dalam program ini yaitu kelompok nelayan dan mitra UKM Bahari Timur diberikan pengetahuan tentang bagaimana mengelola usaha ikan hias mulai dari penangkapan, pengelolaan ikan hias karang yang bernilai tinggi. penanganan, produksi sampai ke pemasarannya
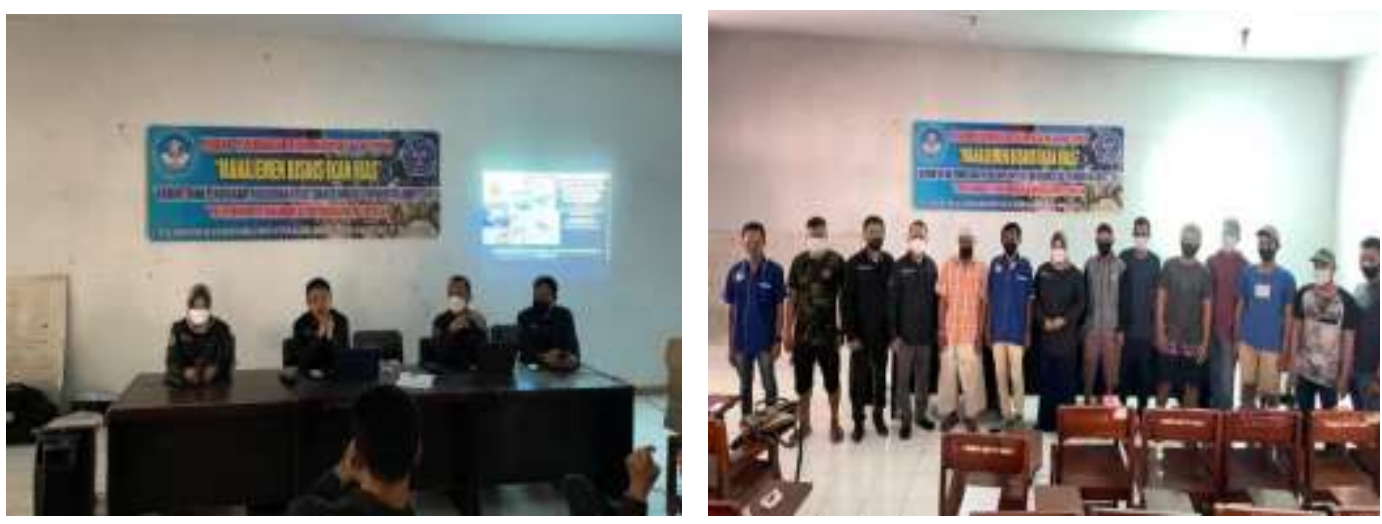

Gambar 1. Pelatihan dan Sosialisasi Manajemen Bisnis

Suatu usaha harus memiliki manajemen usaha yang baik untuk menjaga agar suatu produk tetap eksis di pasaran (Khair et al., 2020).

\section{b. Pembukuan Usaha Ikan Hias}

Selain pelatihan Manajemen bisnis dan pemasaran tim PPPUD juga melakukan pembimbingan dan pendampingan terhadap pengelolaan manajemen keuangan berupa penyusunan laporan keuangan sederhana yaitu pencatatan kas masuk, kas keluar, hutang, piutang dan saldo serta keuntungan dalam satu buku serta ke tahap penyusunan laporan keuangan. Setiap dua kali dalam seminggu dilakukan akan dievaluasi dalam penvtatan dalam buku kas tersebut.

Pada awal kegiatan dimana yang selama ini dilakukan oleh Mitra kelompok nelayan bahwa belum pernah melakukan pembukuan sama sekali, bahkan mereka 
merasa bahwa usahanya ini tidak pernah menguntungkan, padahal sumber keuangan keluarga bergabung dengan keuangan usaha. Itulah yang sebabnya hasil usaha tidak dirasakan karna tidak adanya pencatatan keuangan. Masih disayangkan pelaku UKM belum disiplin dalam melakukan pencatatan keuangan dan mengesampingkannya. Hal ini disebabkan penyusunan laporan keuangan yang dianggap rumit dan memakan waktu (Fadila et al., 2021)

Begitupula pengelolaan administrasi keuangan yang telah dibuat oleh $\mathrm{CV}$. Resky Bahari. Dimana pencatatan yang sudah dibuat yaitu buku kas masih menggunakan sistem pencatatan manual. Dalam setiap proses pendampingan dalam pembuatan laporan keuangan berupa laporan arus kas, laporan Rugi Laba dan Neraca CV. Resky Bahari terlebih dimana telah dibuatkan form dan aplikasi dalam bentuk microsof Excell. Tujuannya adalah untuk medokumentasikan berapa jumlah uang kas masuk dan transaksi pengeluaran. Pada keadaaan ini juga para tim melakukan pendampingan terkait penyusunan laporan Modal dan asset maupun hutan dan piutang yang dimiliki oleh CV. Resky Bahari. Selanjutnya modal dan asset, serta piutang nantinya akan disusun menjadi laporan keuangan. Dari pendampingan yang dilakukan dalam pembuatan laporan keuangan sederhana, antusias dari CV. Resky Bahari cukup tertarik dan diterima dengan baik. Adapun tujuan dari pembuatan laporan keuangan sederhana disini untuk mendapatkan informasi tentang efisiensi dan efektifitas usaha yang sudah berjalan dan juga sebagai bahan kelengkapan bagi untuk memperoleh sumber permodalan dari pihak investor maupun stekeholder yang lain.

Dimensi keberanian dari orientasi kewirausahaan melalui keunggulan bersaing menjadi prinsip bagi setiap pelaku usaha untuk selalu berani dalam menghadapi tantangan usaha, berani mengambil risiko usaha serta berani menentukan strategi yang tepat dalam mengembangkan usaha yang digelutinya agar terwujud keunggulan bersaing terhadap kinerja pemasaran secara representative (Abdullah, 2017).

Keberadaan UMKM tidak dapat dihapuskan ataupun dihindarkan dari masyarakat bangsa saat ini. Karena keberadaannya sangat bermanfaat dalam hal pendistribusian pendapatan masyarakat. Selain itu juga mampu menciptakan kreatifitas yang sejalan dengan usaha untuk mempertahankan dan mengembangkan unsur-unsur tradisi dan kebudayaan masyarakat setempat (Ramadhanti et al., 2021).

\section{Sosialisasi Regulasi Pemasaran Ikan Hias}

Dalam pelatihan ini peserta diberikan sosialisasi tentang regulasi pemasaran ikan hias saat ini sudah berbeda dari yang sebelumnya dimana beberapa prosedur yang harus dilakukan yakni dimulai dari pengiriman sampel ikan untuk diuji kesehatannya di Balai Karantina Ikan sebagai syarat terbitnya sertifikat HC (Health Certificate) pada setiap jenis ikan yang akan dikirim minimal 65\% dari jenis yang akan dilalu lintaskan/ dikirim. Teruntuk perusahaan yang sudah bersertifikat CKIB tidak wajib mengirim sampel tiap melakukan pengiriman cukup sekali sampel dalam jangka waktu 1bulan. Melakukan Pembuatan Packing List 
pengiriman tiap box yang akan dikirim. Kemudian dilakukan pengajuan PPK ONLINE (Permohonan Pemeriksaan Karantina ikan sebagai dokumen pengiriman yang siap untuk di proses sertifikat HC (Health Certificate). Langkah selanjutnya melakukan pemberitahuan melalui Aplikasi Livechat/ SIPETTA.apk kepada petugas pelayanan setibanya barang dibandara agar PPK online dapat diproses dan pemeriksaan fisik barang dalam box dan selanjutnya dilakukan penyegelan box, Penerbitan Sertifikat HC (Health Certificate) oleh petugas BKIPM sebagai dokumen mutu ikan yang akan dikirim. Dan yang terakhir adalah penimbangan dan proses loading.

Hasil pelatihan yang telah dilaksanakan untuk UKM dapat dilihat dibawah ini dengan prosedur pengajuan ppk untuk kegiatan pengiriman ikan hias sebagai berikut:

1. Melakukan Pengiriman sampel ikan untuk diuji kesehatanya di balai karantina ikan sebagai syarat terbitnya sertifikat HC (Health Certificate) pada setiap jenis ikan yang akan dikirim minimal $65 \%$ dari jenis yang akan dilalulintaskan/dikirim (teruntuk Perusahaan yang sudah bersertifikat CKIB tidak wajib mengirim sampel tiap melakukan pengiriman cukup sekali sampel dalam jangka waktu 1 bulan.

2. Melakukan Pembuatan Packing List pengiriman tiap box yang akan dikirim

3. Pengajuan PPK ONLINE (Permohonan Pemeriksaan Karantina ikan sebagai dokumen pengiriman yang siap untuk di proses sertifikat HC (Health Certificate).

4. Melakukan Pemberitahuan Melalui Aplikasi Livechat/SIPETTA.apk kepada petugas pelayanan setibahnya barang dibandara agar PPKonline dapat diproses dan Pemeriksaan Fisik barang dalam box dan selanjutnya dilakukan Penyegelan box,

5. Penerbitan Sertifikat HC (Health Certificate) oleh petugas BKIPM sebagai document mutu ikan yang akan dikirim.

6. Penimbangan dan Proses Loading.

Perubahan yang dapat dilihat antara sebelum dan sesudah pelatihan serta pendampingan sangat berbeda sekali, antara lain dalam pemahaman dalam hal penerapan manejemen bisnis bagaimana mengelola usaha ikan hias mulai dari cara penangkapan yang baik dan ramah lingkungan, memilih jenis ikan hias karang yang bernilai tinggi. Bagaimana melakukan penanganan ikan hias sampai ke pasar, serta pemmahaman tentang regulasi dan pemasaran ikan hias yang sesuai peraturan pemerintah saat ini.

Sebelum pendampingan dalam teknik penangkapan maupun pengelolaan ikan hias belum dilakukan sesuai proseduar yang benar, belum melakukan penggunaan alat tangkap ramah lingkungan, sehingga aspek lingkungan dan kelestarian ekosistem biota laut tersebut bisa terjaga. Pendampingan dan pelatihan kepada mitra sangat membantu sekali dalam penanganan ikan hias, cara 
penanganan yang baik dan benar mulai dari tingkat nelayan sampai ke perusahaan pengekspor bisa terjaga kualitas produksinya. Program pengabdian pada masyarakat ini juga banyak memberi perubahan bagi mitra khususnya dalam manajemen pemasaran. Perubahan yang terjadi dalam hal ini adalah diketahuinya sistem pemasaran yang efektif dalam usaha ikan karang hias, serta pengajuan Permohonan Pemeriksaan Karantina Ikan (PPK) online dengan benar,

Hasil evaluasi dari Program Peningkatan Produk Unggulan Daerah (PPPUD) Ikan Hias karang di Pulau Barrang Lompo Kota Makkasar ini, dalam hal manajemen dan tata kelola usaha Ikan Hias Karang. Begitupun perubahan yang terjadi dalam hal Omset dan pendapatan menunjukkan hasil peningkatan selama program berlangsung yaitu sejak tahun pertama sampai tahun terakhir ini dapat dilihat pada tabel dibawah ini :

Tabel 1. Trend Omset Penjualan Ikan Hias Karang Mitra

\begin{tabular}{crrr}
\hline Nama Mitra & Tahun 2019 & Tahun 2020 & Tahun 2021 \\
\hline Mitra 1 (UKM bahari Timur) & 85.000 .000 & 106.250 .000 & 134.937 .500 \\
\hline Mitra 2 (CV. Rezky Bahari) & 185.000 .000 & 208.750 .000 & 225.062 .500 \\
\hline Total (Rp) & 270.000 .000 & 315.000 .000 & 360.000 .000 \\
\hline
\end{tabular}

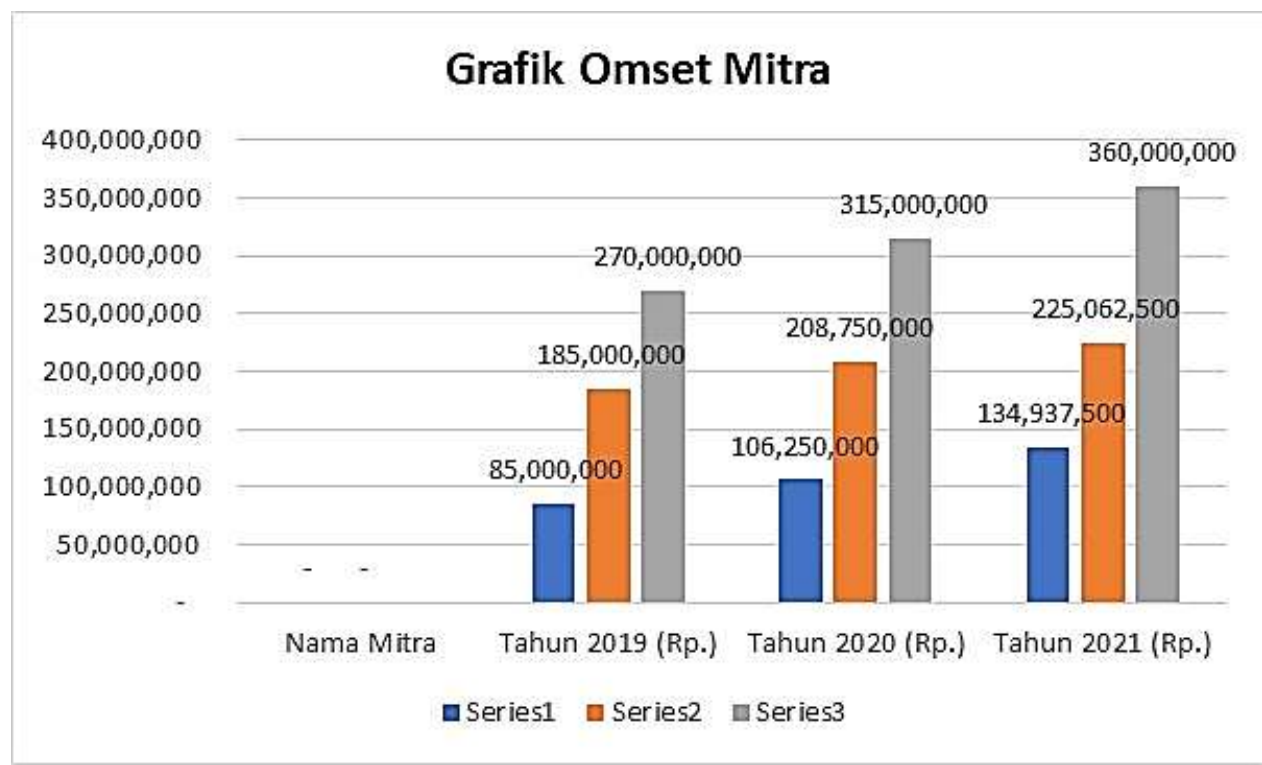

Gambar 2. Grafik Omset Mitra

\section{c. Penyerahan Bantuan ke Mitra}

Pada kegiatan ini juga diberikan bantuan 1 (satu) set peralatan selam dan kelengkapannya kepada mitra. Peralatan ini diterima oleh perwakilan dari mitra kelompok nelayan yang melakukan penangkapan ikan hias karang di sekitar pulau Barrang Lompo Kota Makassar. Dengan perlengkapan ini diharapkan jumlah hasil tangkapan ikan hias karang bisa meningkat dari sebelumnya. Dimana sebelum kegiatan para nelayan hanya menggunakan compressor sebagai alat bantu menyelam. 

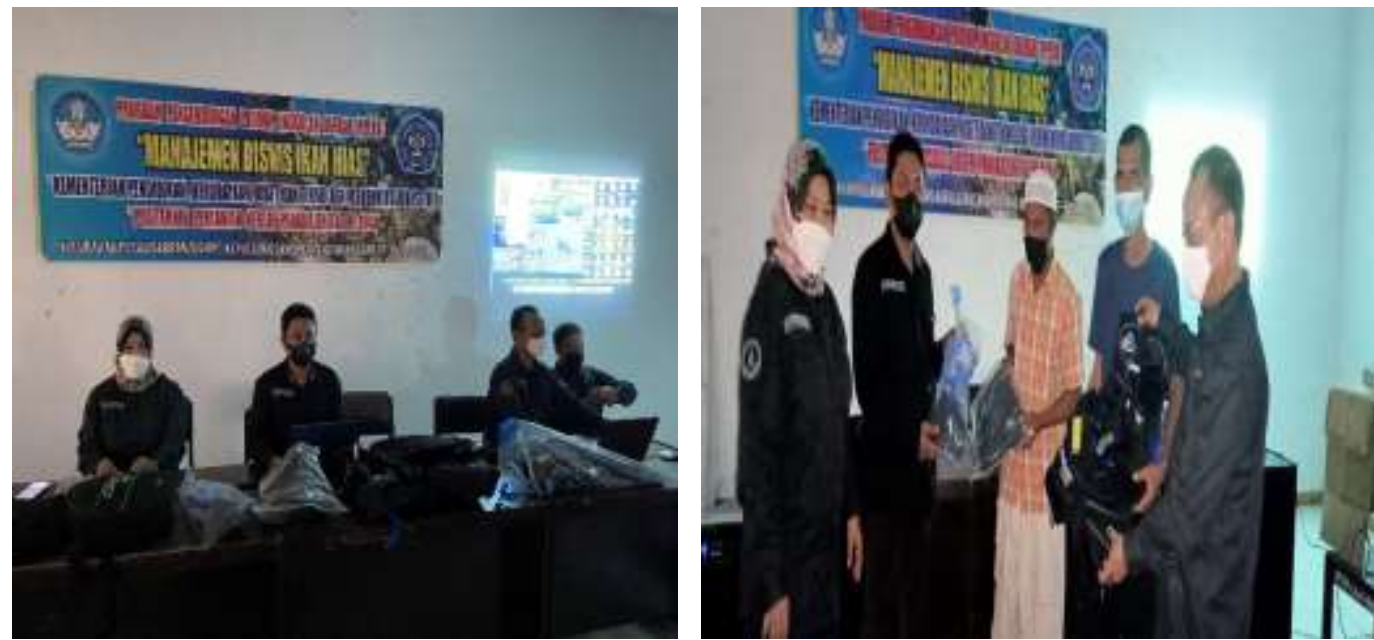

Gambar 3. Penyerahan Bantuan Peralatan Selam kepada Mitra.

\section{Kesimpulan}

Hasil yang diperoleh dari kedua mitra dengan kegiatan ini PPPUD ini bahwa dapat disimpulkan sebagai berikut: (1) meningkatnya pengetahuan dan keterampilan mitra dalam penerapan manajemen bisnis yang baik serta tata kelola usaha. (2). Meningkatnya pengetahuan tentang teknik pemasaran ikan hias karang yang lebih modern, (3). Tertibnya pengadministrasi keuangan usaha mitra, sehingga pembukuan usaha mitra sudah tercatat dengan baik dan benar. (4) Pengetahuan tentang regulasi pemerintah tentang perdagangan bisnis ikan hias karang. Dengan demikian upaya peningkatan pendapatan dari mitra bisa mengalami kemajuan.

\section{Ucapan Terimakasih}

Terima kasih disampaikan kepada Direktorat Riset dan Pengabdian Kepada Masyarakat (DRPM), Kementerian Pendidikan, kebudayaan Riset dan Teknologi yang telah mendanai pelaksanaan program PPPUD ini. Tak lupa pula kami ucapkan banyak terima kasih kepada bapak Direktur Politeknik Pertanian Negeri Pangkajene dan Kepulauan, Pusat Penelitian dan Pengabdian Masyarakat (P3M) Politeknik Pertanian Negeri Pangkep, Mitra UKM Bahari Timur dan kelompok nelayan serta Pemerintah Kota Makassar yang telah bekerjasama dalam pelaksanaan kegiatan ini.

\section{Daftar Pustaka}

Abdullah, A. (2017). Inovasi, Orientasi Pasar, Kompetensi dan Orientasi Kewirausahaan Pengaruhnya Terhadap Keunggulan Bersaing dan Kinerja Pemasaran Pada UMKM Pengolahan Rumput Laut di Sulawesi Selatan. Universitas Muslim Indonesia.

Abdullah, A., Kasmi, M., Karma, K., \& Ilyas, I. (2021). Pengembangan Usaha Kecil Dan Menengah (UKM) Ikan Hias Melalui Pelatihan Pembuatan 
Aquarium. To Maega: Jurnal Pengabdian Masyarakat, 4(2), 231. https://doi.org/10.35914/tomaega.v4i2.786

Abdullah, A., Kasmi, M, Karma, \& Ilyas. (2020). Aplikasi Teknologi Program Pengembangan Produk Unggulan Daerah (PPPUD); Produksi Ikan Hias Karang Lestari di Pulau Barrang Lompo, Makassar, Sulawesi Selatan. Dinamisia : Jurnal Pengabdian Kepada Masyarakat. https://doi.org/10.31849/dinamisia.v4i4.4122

Anggoro, S., Suryanti, S., \& Marwadi, A. (2013). Pengaruh Penggunaan Alat Tangkap Ikan Hias Ramah Lingkungan Terhadap Tingkat Kerusakan Terumbu Karang Di Gosong Karang Lebar Kepulauan Seribu. Diponegoro Journal of Maquares (Management of Aquatic Resources).

Fadila, A., Sholihah, D. R., \& Nugraheni, S. (2021). Pembinaan Pengelolaan Keuangan dan Pemasaran Digital pada pelaku UKM Kecamatan Ciomas Bogor. To Maega: Jurnal Pengabdian Masyarakat, 4(2), 221. https://doi.org/10.35914/tomaega.v4i2.782

Kementerian Kelautan dan Perikanan. (n.d.). Kementerian Kelautan dan Perikanan. https://kkp.go.id/djpdspkp/page/2202-realisasi-investasi-sektorkelautan-dan-perikanan

Khair, U., Sherly, E. N., \& Zulfa, Z. (2020). Pemberdayaan Masyarakat Melalui Pelatihan Manajemen Usaha Pada Pelaku Usaha Dodol Kopi Di Desa Sumber Sari Kecamatan Kabawetan Kabupaten Kepahiang. Jurnal Pengabdian Masyarakat Bumi Raflesia, 3(2). https://doi.org/10.36085/jpmbr.v3i2.745

Mauli Kasmi, Asriany, Andi Ridwan Makkulawu, Arif Fuddin Usman, H. K. (n.d.). Aplikasi Teknologi Pengembangan Budidaya Karang Hias Lestari Sebagai Mata Pencaharian Alternatif di Pulau Barrang Lompo Makassar, Sulawesi Selatan Application of Development Technology for Sustainable Ornamental Corals Aquaculture as Alternative Income I. 5(3). https://doi.org/https://doi.org/10.20956/pa.v5i3.13893

Mulasari, S. A., Tentama, F., Sukesi, T. W., \& Yuliansyah, H. (2021). Penyuluhan dan Pelatihan Kewirausahaan Sebagai Upaya Peningkatan Intensi B erwirausaha pada UKM ” Bangkit ”. 5(4), 866-870.

Pagalung, G., Aswan, A., Perikanan, D., Kelautan dan Perikanan, F., \& Hasanuddin, U. (2020). Prosiding Simposium Nasional VII Kelautan dan Perikanan 2020 Fakultas Ilmu Kelautan dan Perikanan. Universitas Hasanuddin, $\quad 0(7), \quad 187-194 . \quad \mathrm{http} / /$ journalold.unhas.ac.id/index.php/proceedingsimnaskp/article/view/10804

Ramadhanti, M., Lestari, A. R., Dewi, D. F., Indrawati, T., Hilda, K. D., Kusniati, A., Setyawan, A., \& Ahsan, M. (2021). Pemberdayaan Masyarakat Melalui Pengembangan Usaha Budidaya Lele Dalam Menghadapi Pandemi Covid-19. Jurnal Pengabdian Masyarakat, 2(1), 8-14. 
[ 405 ] Akmal Abdullah, dkk / To Maega : Jurnal Pengabdian Masyarakat, Vol.4; No.3; Oktober 2021

https://jurnal.stie.asia.ac.id/index.php/jpm/article/view/274

Riyadi, N., \& Mujanah, S. (2021). Strategi Pemasaran Dan Pendampingan Manajemen Usaha Kelompok Usaha Kecil Kerupuk Di Kenjeran Kota Surabaya. Jurnal Ilmiah Abdi Mas TPB Unram, 3(1). https://doi.org/10.29303/amtpb.v3i1.56

Suci, Y. R., Tinggi, S., \& Ekonomi, I. (2017). Perkembangan UMKM (Usaha Mikro Kecil Menengah) di Indonesia. Jurnal Ilmiah Fakultasi Ekonomi. 